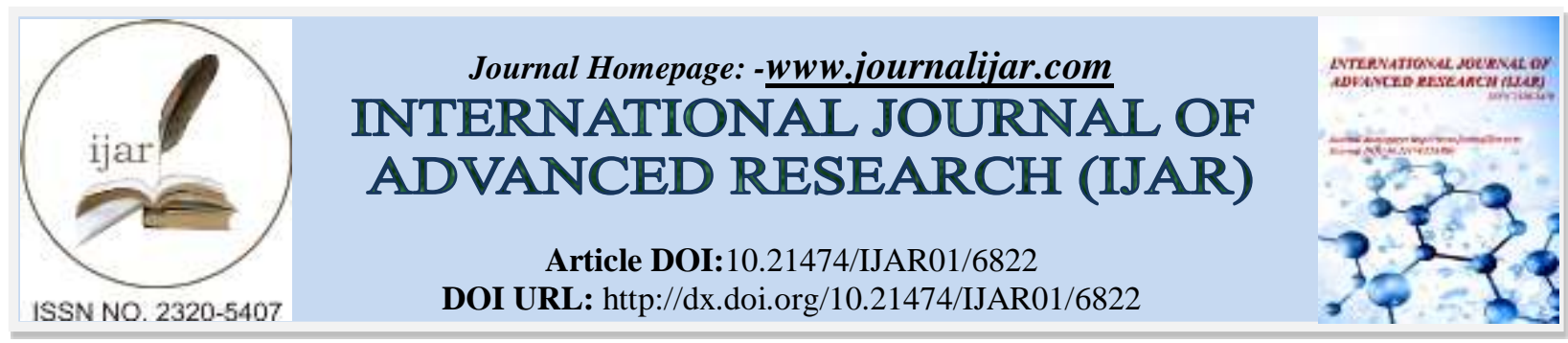

RESEARCH ARTICLE

\title{
PALYNOLOGICAL ANALYSIS OF SOME ACCESSIONS OF MANGIFERA INDICA L. FROM KANYAKUMARI AND THIRUVANANTHAPURAM DISTRICTS OF SOUTH INDIA, INDIA.
}

Smitha. M. V and David Samuel. P.

Department of Botany and Research Centre, Nesamony Memorial Christian College (NMCC) Marthandam, Kanyakumari District, Tamil Nadu, India.

\section{Manuscript Info}

..........................

Manuscript History

Received: 02 February 2018

Final Accepted: 04 March 2018

Published: April 2018

Keywords:-

Mangifera indica $\mathrm{L}$., accessions, pollen morphology, tri-colporate, sub-prolate, prolate-spheroidal.

\section{Abstract}

The pollen morphology of nine accessions of Mangifera indica $\mathrm{L}$ were elucidated with scanning electron microscopy (SEM), supplemented by light microscopy (LM) and micrometry. The pollen grains of all accessions were tri-zonocolporate. The shape of the pollen was ranged from sub-prolate to prolate-spheroidal. With regard to exine ornamentation, striate reticulate pattern was the most dominant condition, while striate elongate pattern was rarely observed. Similarly striate reticulate condition with foveolate appearance was also observed in certain accessions. Ectoexine was found to be thicker than endoexine. Exine thickness, colpus length, colpus breadth, apocolpium and mesocolpium were also measured.

Copy Right, IJAR, 2018,. All rights reserved.

\section{Introduction:}

The genus Mangifera belongs to the order Sapindales includes the family Anacardiaceae with more than 40 species around the world and 15 species bear edible fruits (Abhishkar Subedi et al., 2008). Mangifera indica L, the king of fruit is one of the high potential fruits and suitable for different agro-ecological zones ranging from sub-humid to semi-arid. Mango tree was reported in Somalia as early as 1331 (Griesbach, 2003). In India the emperor Akbar who reigned in Northern India from 1556-1605 planted an orchard of a hundred thousand mango trees. Because of the fossil records and the presence of plenty of wild and cultivated varieties in India, it was stated that the region of mango origin was most likely Indo- Burma. Vavilov (1926) also suggested Indo-Burma region as the Centre of origin of mango.

Mango has become naturalized and adapted throughout the tropics and subtropics. There are over 1000 named mango varieties throughout the world, with India having the greatest number of over 500, is a testament to their value to human kind (Ian .S.E.Bally.,2006). Pollen, is the most vital unit in the flower biology of plants. The pollen characters are of diagnostic value and of comparative importance in taxonomy and evolutionary considerations at all taxa levels (Nair, 1991, 2004) and may be even at the level of individuals in plant population. The importance of pollen in evolutionary schemes of the plant kingdom was first formulated by Wodehouse (1935) and later by several authors (Nair, 1965; Walker and Doyle, 1975; Muller, 1970; Chaloner, 1967). Later a lot of studies have been reported by many authors in different families. Of which one is Solanaceae, it is considered as one of the most advanced family and this fact is confirmed by the tri-zonocolporate nature of pollen grains as reported by many authors, which is similar to the pollengrains of Mangifera indica $\mathrm{L}$. 
Very few studies related to mango pollen has been reported, of which one is, a preliminary study of the pollen of Mangifera indica L.cv Haden in South Africa (Esme de Wet and P.J.Robberste, 1986). Conservation of these accessions of mango is essential because they are increasingly threatened in the world. For the conservation of germplasm and their further genetic improvement pollen grain is inevitable resource. In such a backdrop, the present work focuses on the detailed account of the pollen morphological characterization of some accessions of Mangifera indica $\mathrm{L}$.

\section{Materials and Methods:}

The polliniferous materials for the present investigation were procured from plants growing in different localities of Thiruvananthapuram and Kanyakumari district. The accessions selected for the study were Kottookonam, Kaarali, Thottu, Selan, Karppurm, Pandi, Kappa, Chunnakannan and Valakkachi. Pollen grains used in the present study were collected from fresh and mature buds of inflorescence and were preserved in $70 \%$ ethanol. Further procedure of microscopic preparations was as per the standard method of acetolysis (Erdtman 1952., Nair 1960).

Data on pollen morphology have been generated through LM \& SEM studies on the photographs of pollen samples, which revealed the detailed surface ornamentations on the general appearance, which were developed by the magnification by $1000 \mathrm{X}$. In deducting the size of the pollen grains, 20 grains were taken randomly. Parameters such as pollen diameter $\mathrm{P}$, equatorial diameter $\mathrm{E}, \mathrm{P} / \mathrm{E}$ ratio, shape, exine thickness, apocolpium, mesocolpium, colpus length, colpus breadth were recorded. The technical description of the pollen grains was carried out in accordance with the technical terminology used by Punt et al., (2007).

\section{Results:}

The comparative analysis revealed that pollen grains, of nine accessions of Mangifera indica L. were 3zonocolporate. All the studied characters in the present study is summarized in table1.

Table 1:- Pollen characters of different accessions of Mango

\begin{tabular}{|c|c|c|c|c|c|c|c|c|c|c|c|}
\hline $\begin{array}{l}\text { Sl } \\
\text { n } \\
\text { o }\end{array}$ & $\begin{array}{c}\text { Name of } \\
\text { accessions }\end{array}$ & $\begin{array}{c}\text { Polar } \\
\text { Diamet } \\
\text { er }\end{array}$ & $\begin{array}{c}\text { Equato } \\
\text { rial } \\
\text { Diamet } \\
\text { er }\end{array}$ & $\begin{array}{c}\text { P/E } \\
\text { rati } \\
\text { o }\end{array}$ & Shape & $\begin{array}{c}\text { Exine } \\
\text { ornamen } \\
\text { tation }\end{array}$ & $\begin{array}{c}\text { Exine } \\
\text { thick } \\
\text { ness }\end{array}$ & $\begin{array}{c}\text { Colp } \\
\text { us } \\
\text { lengt } \\
\text { h }\end{array}$ & $\begin{array}{c}\text { Colp } \\
\text { us } \\
\text { brea } \\
\text { dth }\end{array}$ & $\begin{array}{c}\text { Apo } \\
\text { colpi } \\
\text { um }\end{array}$ & $\begin{array}{c}\text { Meso } \\
\text { colpi } \\
\text { um }\end{array}$ \\
\hline 1 & $\begin{array}{l}\text { Kotookonam } \\
\text { varikka }\end{array}$ & $31 \mu \mathrm{m}$ & $26 \mu \mathrm{m}$ & $\begin{array}{l}119 \\
\mu \mathrm{m}\end{array}$ & $\begin{array}{l}\text { Sub- } \\
\text { prolate }\end{array}$ & $\begin{array}{l}\text { Striate } \\
\text { reticulate }\end{array}$ & $2 \mu \mathrm{m}$ & $\begin{array}{l}24 \\
\mu \mathrm{m}\end{array}$ & $5 \mu \mathrm{m}$ & $\begin{array}{l}17 \\
\mu \mathrm{m}\end{array}$ & $11 \mu \mathrm{m}$ \\
\hline 2 & Kaarali & $30 \mu \mathrm{m}$ & $25 \mu \mathrm{m}$ & $\begin{array}{l}120 \\
\mu \mathrm{m}\end{array}$ & $\begin{array}{l}\text { Sub- } \\
\text { prolate }\end{array}$ & $\begin{array}{l}\text { Striate } \\
\text { elongate }\end{array}$ & $\begin{array}{l}1.5 \\
\mu \mathrm{m}\end{array}$ & $\begin{array}{l}18 \\
\mu \mathrm{m}\end{array}$ & $1 \mu \mathrm{m}$ & $\begin{array}{l}15 \\
\mu \mathrm{m}\end{array}$ & $8 \mu \mathrm{m}$ \\
\hline 3 & Thottu & $23 \mu \mathrm{m}$ & $20 \mu \mathrm{m}$ & $\begin{array}{l}115 \\
\mu \mathrm{m}\end{array}$ & $\begin{array}{l}\text { Sub- } \\
\text { prolate }\end{array}$ & $\begin{array}{l}\text { Striate } \\
\text { reticulate }\end{array}$ & $2 \mu \mathrm{m}$ & $\begin{array}{l}18 \\
\mu \mathrm{m}\end{array}$ & $4 \mu \mathrm{m}$ & $\begin{array}{l}11 \\
\mu \mathrm{m}\end{array}$ & $7 \mu \mathrm{m}$ \\
\hline 4 & Selan & $27 \mu \mathrm{m}$ & $23 \mu \mathrm{m}$ & $\begin{array}{l}117 \\
\mu \mathrm{m}\end{array}$ & $\begin{array}{l}\text { Sub- } \\
\text { prolate }\end{array}$ & $\begin{array}{l}\text { Striate } \\
\text { reticulate }\end{array}$ & $1 \mu \mathrm{m}$ & $\begin{array}{l}15 \\
\mu \mathrm{m}\end{array}$ & $3 \mu \mathrm{m}$ & $\begin{array}{l}13 \\
\mu \mathrm{m}\end{array}$ & $\begin{array}{l}15 \\
\mu \mathrm{m}\end{array}$ \\
\hline 5 & Karppuram & $24 \mu \mathrm{m}$ & $21 \mu \mathrm{m}$ & $\begin{array}{l}114 \\
\mu \mathrm{m}\end{array}$ & $\begin{array}{l}\text { Prolate- } \\
\text { spheroidal }\end{array}$ & $\begin{array}{l}\text { Striate } \\
\text { reticulate }\end{array}$ & $2 \mu \mathrm{m}$ & $\begin{array}{l}14 \\
\mu \mathrm{m}\end{array}$ & $3 \mu \mathrm{m}$ & $\begin{array}{l}11 \\
\mu \mathrm{m}\end{array}$ & $\begin{array}{l}13 \\
\mu \mathrm{m}\end{array}$ \\
\hline 6 & Pandi & $24 \mu \mathrm{m}$ & $21 \mu \mathrm{m}$ & $\begin{array}{l}114 \\
\mu \mathrm{m}\end{array}$ & $\begin{array}{l}\text { Prolate- } \\
\text { spheroidal }\end{array}$ & $\begin{array}{l}\text { Striate } \\
\text { reticulate }\end{array}$ & $1 \mu \mathrm{m}$ & $\begin{array}{l}12 \\
\mu \mathrm{m}\end{array}$ & $3 \mu \mathrm{m}$ & $\begin{array}{l}12 \\
\mu \mathrm{m}\end{array}$ & $\begin{array}{l}14 \\
\mu \mathrm{m}\end{array}$ \\
\hline 7 & Kappa & $29 \mu \mathrm{m}$ & $25 \mu \mathrm{m}$ & $\begin{array}{l}116 \\
\mu \mathrm{m}\end{array}$ & $\begin{array}{l}\text { Sub- } \\
\text { prolate }\end{array}$ & $\begin{array}{l}\text { Striate } \\
\text { reticulate }\end{array}$ & $\begin{array}{l}1.5 \\
\mu \mathrm{m}\end{array}$ & $\begin{array}{l}21 \\
\mu \mathrm{m}\end{array}$ & $2 \mu \mathrm{m}$ & $\begin{array}{l}11 \\
\mu \mathrm{m}\end{array}$ & $\begin{array}{l}16 \\
\mu \mathrm{m}\end{array}$ \\
\hline 8 & $\begin{array}{l}\text { Chunnakann } \\
\text { an }\end{array}$ & $21 \mu \mathrm{m}$ & $20 \mu \mathrm{m}$ & $\begin{array}{l}105 \\
\mu \mathrm{m}\end{array}$ & $\begin{array}{l}\text { Prolate- } \\
\text { spheroidal }\end{array}$ & $\begin{array}{l}\text { Striate } \\
\text { reticulate }\end{array}$ & $2 \mu \mathrm{m}$ & $\begin{array}{l}14 \\
\mu \mathrm{m}\end{array}$ & $3 \mu \mathrm{m}$ & $\begin{array}{l}12 \\
\mu \mathrm{m}\end{array}$ & $\begin{array}{l}18 \\
\mu \mathrm{m}\end{array}$ \\
\hline 9 & Valakkachi & $\begin{array}{l}21.5 \\
\mu \mathrm{m}\end{array}$ & $20 \mu \mathrm{m}$ & $\begin{array}{l}107 . \\
5 \\
\mu \mathrm{m}\end{array}$ & $\begin{array}{l}\text { Prolate- } \\
\text { spheroidal }\end{array}$ & $\begin{array}{l}\text { Striate } \\
\text { reticulate }\end{array}$ & $\begin{array}{l}1.5 \\
\mu \mathrm{m}\end{array}$ & $\begin{array}{l}12 \\
\mu \mathrm{m}\end{array}$ & $3 \mu \mathrm{m}$ & $\begin{array}{l}12 \\
\mu \mathrm{m}\end{array}$ & $\begin{array}{l}16 \\
\mu \mathrm{m}\end{array}$ \\
\hline
\end{tabular}

\subsection{Pollen description of different accessions of Mangifera indica $\mathrm{L}$ :}

Kotookonamvarikka: (Figure 1:1A, 1B): Pollen grains 3-zonocolporate and shape sub-prolate. Exine ornamentation striate reticulate with lateral fusion of striae visible. Exine thickness was $2 \mu \mathrm{m}$. Size of pollen: $28-33 \mu \mathrm{m}$ (PD) x $24-$ $28 \mu \mathrm{m}$ (ED). Colpus length was $24 \mu \mathrm{m}$, colpus breadth was $5 \mu \mathrm{m}$, apocolpium was $17 \mu \mathrm{m}$ and mesocolpium was $11 \mu \mathrm{m}$ respectively. 
Kaaralivarikka: (Figure 2:2A, 2B): Pollen grains 3-zonocolporate. Reticulate condition absent, instead of that, striate- elongated ornamentation was present. Exine thickness was $1.5 \mu \mathrm{m}$. Size of pollen $27-32 \mu \mathrm{m}(\mathrm{PD}) \mathrm{x} 20-30 \mu \mathrm{m}$ (ED), sub-prolate. Colpus length was $18 \mu \mathrm{m}$, colpus breadth was $1 \mu \mathrm{m}$, apocolpium was $15 \mu \mathrm{m}$ and mesocolpium was $8 \mu \mathrm{m}$ respectively.

Thottu: (Figure 3:3A, 3B): Pollen grains 3-zonocolporate and shape sub-prolate. Exine ornamentation striate

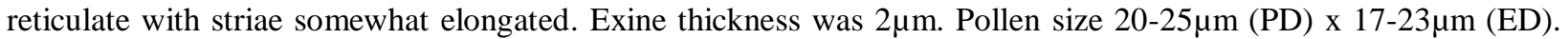
Colpus length was $18 \mu \mathrm{m}$, colpus breadth was $4 \mu \mathrm{m}$, apocolpium $11 \mu \mathrm{m}$ and mesocolpium was $7 \mu \mathrm{m}$ respectively.

Selan: (Figure 4: 4A, 4B): Pollen grains 3-zonocolporate and shape sub-prolate. Exine ornamentation striate reticulate with muri systematically intertwined into a network. Fusion of striae observed at the colpus region. Operculam narrow and sunken. Exine thickness was $1 \mu \mathrm{mm}$.Size of pollen 21-32 $\mu \mathrm{m}$ (PD) x 18-27 $\mu \mathrm{m}$ (ED). Colpus length was $15 \mu \mathrm{m}$, colpus breadth was $3 \mu \mathrm{m}$, apocolpium $13 \mu \mathrm{m}$ and mesocolpium was $15 \mu \mathrm{m}$.

Karppuram Manga: (Figure 5: 5A, 5B): Pollen grains 3-zonocolporate and shape prolate - spheroidal. Exine ornamentation striate reticulate with broad striae. Colpus region contains bacculate excrescences. Wide operculum was observed. Exine thickness was $2 \mu \mathrm{m}$. Pollen size $23-25 \mu \mathrm{mm}$ (PD) x20-22 $\mu \mathrm{m}$ (ED). Colpus length was $14 \mu \mathrm{m}$, colpus breadth was $3 \mu \mathrm{m}$, apocolpium was $11 \mu \mathrm{m}$ and mesocolpium was $13 \mu \mathrm{m}$ respectively.

Pandi: (Figure 6: 6A, 6B): Pollen grains 3- zonocolporate and shape Prolate-spheroidal. Exine ornamentation striate reticulate with foveolated appearance. Colpus region was granulate. Muri systematically intertwined into a network. Exine thickness was $1 \mu \mathrm{m}$. Size of pollen: $21-26 \mu \mathrm{m}$ (PD) x 18-24 $\mu \mathrm{m}$ (ED). Colpus length was $12 \mu \mathrm{m}$, colpus width was $3 \mu \mathrm{m}$, apocolpium was $12 \mu \mathrm{m}$ and mesocolpium was $14 \mu \mathrm{m}$.

Kappa: (Figure 7: 7A, 7B): Pollen grains 3-zonocolporate and shape sub-prolate. Exine ornamentation striate reticulate with foveolate and fusion of striae observed. Exine thickness was $1.5 \mu \mathrm{m}$. Pollen size 27- 31 $\mu \mathrm{m}$ (PD) x 21$28 \mu \mathrm{m}$ (ED). Colpus length was $21 \mu \mathrm{m}$, colpus breadth was $2 \mu \mathrm{m}$, apocolpium was $11 \mu \mathrm{m}$ and mesocolpium was $16 \mu \mathrm{m}$ respectively.

Chunnakannan: (Figure (8: 8A, 8B): Pollen grains 3-zonocolporate and shape prolate-spheroidal. Exine ornamentation striate reticulate with very less lateral fusion of striae. Colpus region granulate and narrower. Exine thickness was $2 \mu \mathrm{m}$. Pollen size $18-24 \mu \mathrm{m}$ (PD) $\times 24 \mu \mathrm{m}$ (ED). Colpus length was $14 \mu \mathrm{m}$, colpus breadth was $3 \mu \mathrm{m}$ apocolpium 12, mesocolpium $18 \mu \mathrm{m}$.

Valakkachi: ((Figure 9: 9A, 9B): Pollen grains 3-zonocolporate and shape. Prolate-spheroidal. Exine ornamentation striate reticulate with foveolate appearance. Very less lateral fusion was noticed. Narrow colpus region. Granulate excrescences seen randomly. Exine thickness was $1.5 \mu \mathrm{m}$. Pollen size 19-24 $\mu \mathrm{m}$ (PD) $\times 17-23 \mu \mathrm{m}$ (ED). Colpus length $12 \mu \mathrm{m}$, colpus breadth $3 \mu \mathrm{m}$ apocolpium $12 \mu \mathrm{m}$, mesocolpium $16 \mu \mathrm{m}$.

\section{Palynological delineation of accessions of Mangifera indica $\mathrm{L}$ :}

The observations ascertained that the pollen grains of all the accessions were tricolporate and the exine ornamentation was mostly striate reticulate with muri systematically intertwined into a network. But variations were observed in a few accessions. Although striate elongated condition was noticed in kaarali. Thottu showed striate reticulate condition with striae somewhat elongated. Striate reticulate condition with foveolate appearance was observed in Kappa, Valakkachi and Pandi.

Of the 9 accessions studied the smallest grain was that of Chunnakannan $105 \mu \mathrm{m}$, based on P/E ratio and the largest grain was encountered in Kaarali measured at $120 \mu \mathrm{m}$. Exine thickness varied from 1-2 $\mu \mathrm{m}$ thickness. The grains of the accessions was either sub-prolate or prolate-spheroidal. Excrescences was noticed, which was granulate in Valakkachi and bacculate in Karppuram. Microgranules were randomly spread in the colpus region of Kaarali. Minor variations or additional characteristics give an identification tool for the various accessions. 

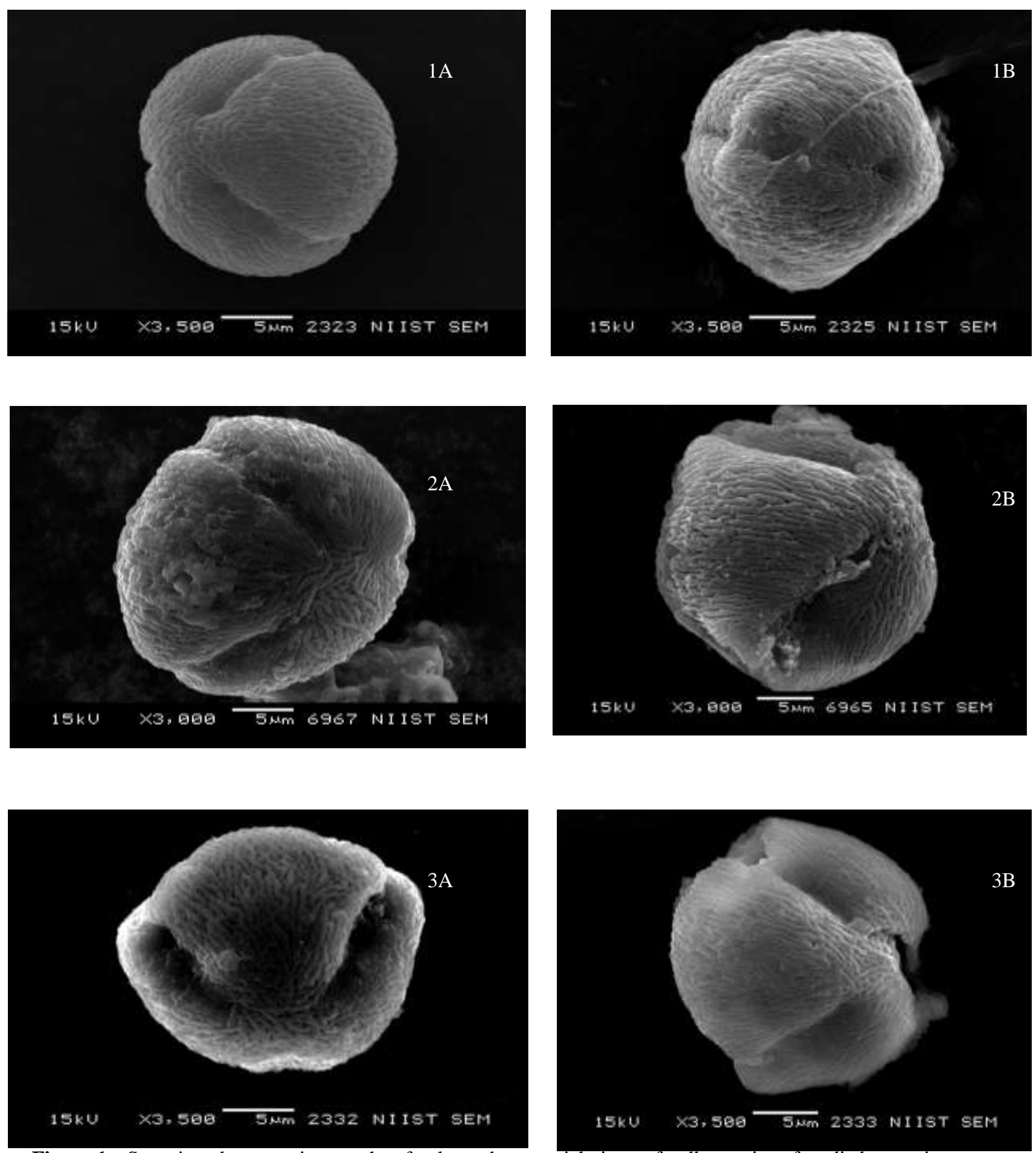

Figure 1:- Scanning electron micrographs of polar and equatorial views of pollen grains of studied accessions: Kotookonam (1A:1B), Kaarali (2A: 2B), Thottu (3A: 3B) 

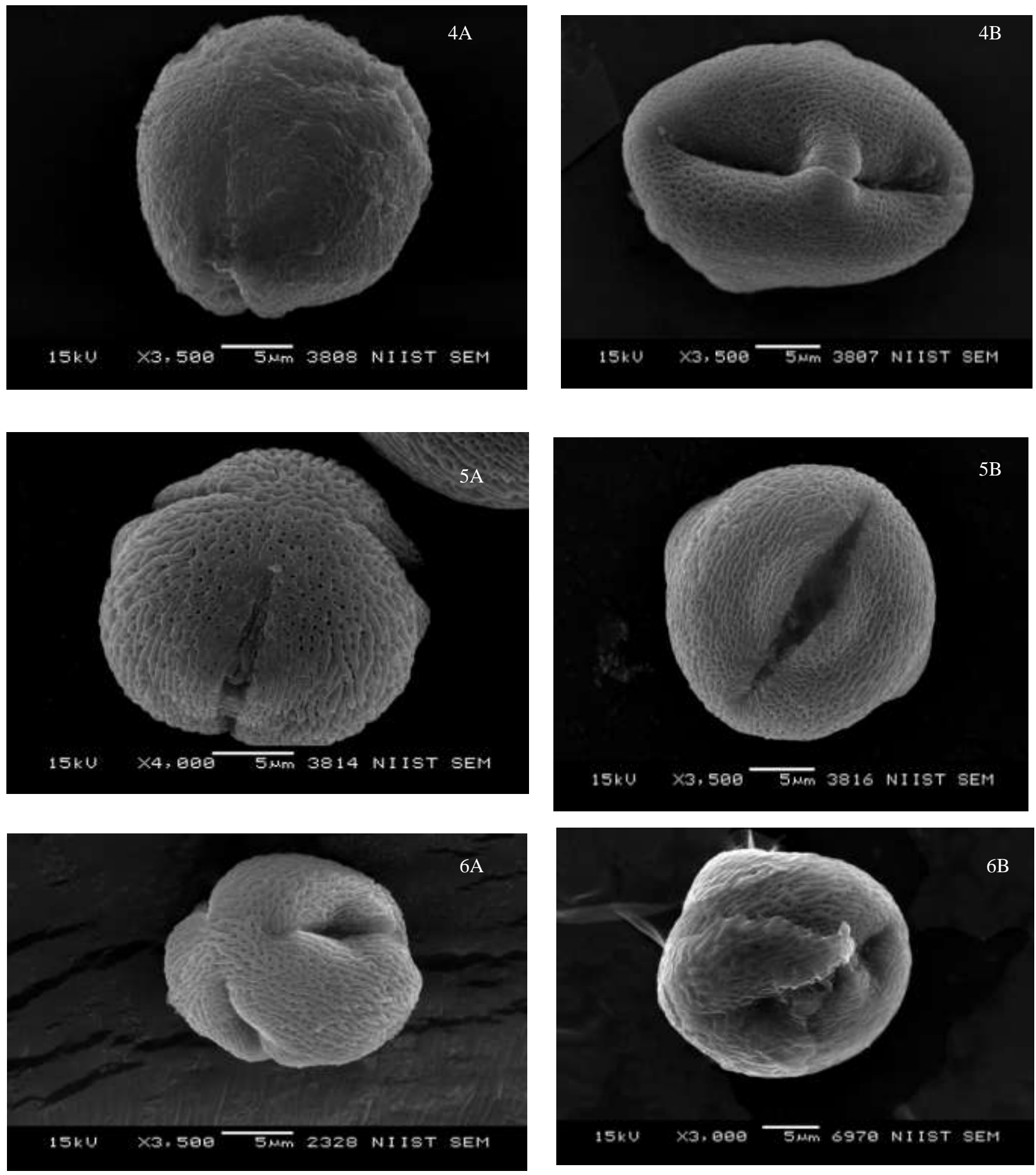

Figure 2:- Scanning electron micrographs of polar and equatorial views of pollen grains of studied accessions: Selan (4A:4B), Karppuram (5A: 5B), Pandi (6A: 6B). 

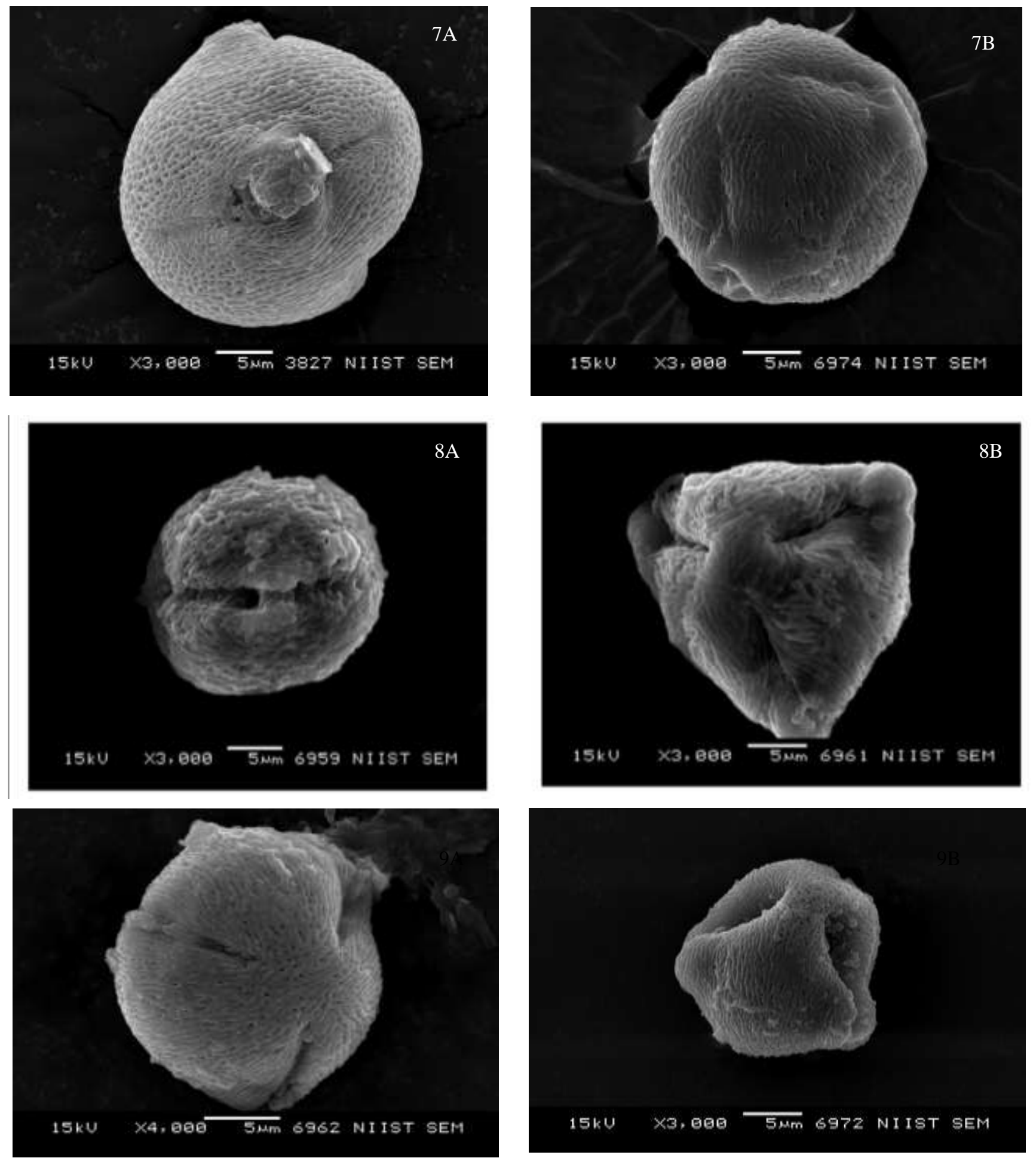

Figure 3:- Scanning electron micrographs of polar and equatorial views of pollen grains of studied accessions: Kappa (7A: 7B), Chunnakannan (8A: 8B), Valakkachi (9A: 9B).

\section{Discussion:-}

In a Lecture to the Royal Society of London in 1809, Robert Brown pointed out that pollen morphology must not be neglected in plant systematics. The pollen morphology is not affected by environmental conditions, hence it has been used as a reliable diagnostic key in the taxonomical researches (Aytug, 1959). Tomb et al (1974) suggested that 
pollen characters particularly those of aperture region, are taxonomically useful in subtribe and the acetolyzed material gives more useful information than untreated one.

Pollen shape, aperture type and sculpturing are usually very useful taxonomic characters. Huang (1972) used pollen characters as an additional aid for systematic purposes. Nair (1960) recorded that, the order Sapindales is characterised by the occurance of 3-colporate grains in a great majority of the families composing it. Grains of Mangifera indica L. were larger and have a very small ora compared with those of Mangifera foetida, previously described by Erdtman, 1952. Pollen morphology of mango showed that the grains were triangular in polar view, 3colporate, sub-prolate $29 \times 24 \mu \mathrm{m}$ (exine baculate, regulate A.N.Roa and Y.K.Lee, 1969). The pollen grains of the entire accessions of Mangifera indica L. in the present study were tri-zonocolporate.

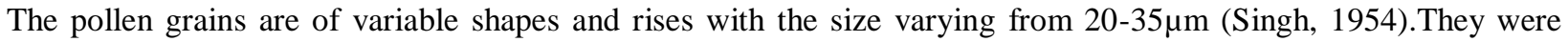
generally triangular in polar view and the shape of the grains varied from prolate- spheroidal to sub-prolate, bywhich $\mathrm{P} / \mathrm{E}$ ratio ranged from $105 \mu \mathrm{m}-120 \mu \mathrm{m}$. $\mathrm{P} / \mathrm{E}$ ratio is a useful taxonomic character to show a range of variation in different taxa, where Chunnakannan had the lowest $\mathrm{P} / \mathrm{E}$ ratio $(105 \mu \mathrm{m})$ while the highest $\mathrm{P} / \mathrm{E}$ ratio was found in Kaarali $(120 \mu \mathrm{m})$. The photographs of pollen samples, which revealed the detailed surface ornamentations on their general appearance were developed, with the dimension ranging from $3000 \mu \mathrm{m}-10,000 \mu \mathrm{m}$.

Earlier investigations of the pollen morphology of Mangifera indica L. revealed that the grains showed striate reticulate ornamentation. In Kaarali striate reticulate condition was absent and instead of that striate elongated condition was noticed. Thottu showed striate reticulate pattern with striae somewhat elongated. But striate-reticulate condition with foveolate appearance was observed in Kappa, Valakkachi and Pandi. Fusion of striae was also observed in some accessions. In Selan fusion of striae was observed at the colpus region. Lateral fusion was very less in Chunnakannan.

There was variation in colpus region, broad and narrow colpus region were noticed in some accessions. The colpi were elongated and boat shaped with acute ends. Bacculate excrescences was observed in Karppuram while in Valakkachi granulate excrescences was seen. Operculum varied in different accessions. Narrow and sunken was observed in Selan. Like ways, wide and narrow operculum was also seen. Exine thickness varies from 1-2 $\mu$ m. Microgranules were randomly spread in the colpus region of Kaarali. Pal, 1992., Pal et at., 1993a, 1993b showed that the taxa having tricolporate pollen grains reveals their advance status whereas taxa with polyad or colpate type of pollen grains shows its primitive status in the evolutionary scale.

\section{Acknowledgements:-}

We wish to thank Head of the Department, Dr.G.Johnsy Christobel and other faculty members of Department of Botany and Research, Nesamony Memorial Christian College Marthandam for their support. We also thanks to Dr.Prabhakar Rao and Mr.M.R.Chandran for providing the SEM facility at NIIST Thiruvananthapuram. Sincere thanks to Dr.P.K.K. Nair and Dr.P.K.Shaji of ERRC, Thiruvanthapuram and Dr.Maya.C.Nair, Asst.Prof.in Botany, Govt.Victoria College Palakkad for their valuable suggestions and help.

\section{References:-}

1. Abishkar Subedi. (2008). Locality and managing the mango (Mangifera indica L.) genetic resources in Nepal. Plant Genetic Resources Newsletter, 2018, No.155:52-61.

2. Anil Arora and Archana Modi. (2011). Pollen Morphology of Some Desertic Crucifers. Indian Journal of Fundamental and Applied Life Sciences pp., 11-15.

3. AnjumPerveen and M.Qaiser. (2007). Pollen morphology of family Solanaceae from Pakistan. Pak. Bot., 39(7): 2243-2256.

4. Anna Tomlik- Wyremblewskla, Raymond W.J.M. Van Der Ham, PiotrKosinski. (2004). Pollen morphology of Genus (1986). A preliminary study of the pollen of Mangifera indica L. cv. Haden in South Africa. S. Afr. Plant Soil, 3(2).

5. A .N. Roa and Y. K. Lee. (1969). Pacific Science, Vol.XXIV, No.2 (1969).

6. Aytug, B. (1967). Palynological Investigations on Important Gymnosperm of Turkey and Pollen Morphology. Istanbul, Turkey.

7. Cecilia Ruth Bila Mussane. (2010). Morphological and Genetic Characterization of Mango (Mangifera indicaL.) varieties in Mozambique. Thesis. University of the Free State, Bloemfontein South Africa. 
8. Erdtman, G. (1968). An introduction to Palynology1. Pollen Morphology and Plant Taxonomy: Angiosperm. Stockholm: Almqvist and Viksell, 539.

9. Esme de wet and P.J. Robbertse, Akbar Ali Meo and Mir Ajab khan. (2003). Palynological Observations on The Genera Zoegia, Cousinia and carduus in the tribe Cynaroideae (Compositae) from Pakistan. Pak. J. Weed Sci Res., 9 (3\&4): 243-252.

10. Fatma Gunes and Burhan Aytug. (2010). Pollen Morphology of the Genus Lathyrus (Fabaceae) Section Pratensis in Turkey. Int. J. Agric. Biol., 12:96-100.

11. Fatma Mungan, Kemal Yildiz,Ersin Minareci and Murat kilic.(2011). Apalynological study of the genus Smyrnium (Umbelliferae) from Turkey. Journal of Medicinal Plants Research. , Vol.5 (6), PP.997-1003.

12. Griesbach.J. (2003). Mango book Kenia. Nairobi, Kenia: World Agroforestry Centre. pp. 4-6.

13. HanifeAkyalcin. (2003). Pollen morphology of Origanum L. (Labiatae) Taxons in Turkiye. Asian Journal of Plant Sciences. , 2(1):28-41.

14. Ian .S.Bally. (2006). Mangifera indica (mango). Species Profiles for Pacific Island Agroforestry Www.traditionaltree .org.

15. Huang, C.T. (1966). Pollen grains of Formosan Plants 1.tai 2.nta.edu.tw/taiwania.

16. K. G. Divya., Maya C Nair, P. K.Shaji and P.K.K. Nair. (2015). Pollen morphology of Pepper Cultivars and their wild allies from Southern Western Ghats, Kerala, India. International Journal of Advanced Research, Vol 3,344-353.

17. Livia Wantorp., Joseph Praglowski and Elisabeth Grafstrom. New insight into the pollen morphology of the Genus Gunnera (Gunneraceae). Grana. , 43:15-21.

18. Moore, P. D., J. A. Webb and M. E. Collinson. (1991). Pollen Analysis. Blackwell Scientific Publications. Oxford, Pp.62-101.

19. Muyeol Kim., Michael S. Zavala. (2011). Pollen morphology of Broussonetia (Moraceae). Grana, 32:327-329, 1993.

20. Nair, P. K. K. (1969). Pollen Morphology of Angiosperm. Vikas publication.2-114.

21. Punt. W., Blackmore. S., Nilson. S., Le Thomas, A. (2007). Glossary of Pollen and Spore Terminology. Rev Palaeobotpalynol, 143:1-81.

22. Rubus L. PART111. Studies on the Malesian species of Subgenera Chamaebatus L. and Idaeobatus L. Acta Societatis Botanicorum Poloniae., Vol 73. No: 207-227.

23. Singh,R. N. (1954). Studies on the floral biology and subsequent development of fruit in the mango varieties Dashehari and Langra. Indian J.Horti, 11(1):69-88.

24. Tomb, A. S., D.A. Larson and J. J. Skvarla. (1974). Pollen morphology and detailed structure of family Compositae, tribe Cichoriea 1.Subtribe Stephanomesiinae, Amer. J. Bot. 61: 486-498.

25. Vavilov, N.I. (1926). Centres of origin of cultivated plants, Bulletin of Applied Botany, Genetics and Plant Breeding, 16: pp1-248. 